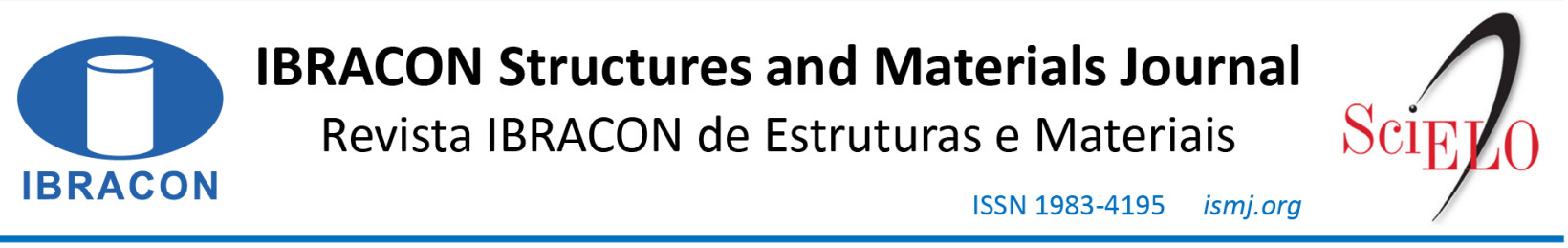

ORIGINAL ARTICLE

\title{
Numerical analysis of the influence of block geometry on the behavior of piled foundations
}

\section{Análise numérica da influência da geometria do bloco no comportamento de fundações estaqueadas}

\author{
Jean Rodrigo Garcia ${ }^{\mathrm{a}}$ \\ Paulo José Rocha de Albuquerque ${ }^{\mathrm{b}}$
}

${ }^{a}$ Universidade Federal de Uberlândia - UFU, Faculdade de Engenharia Civil, Uberlândia, MG, Brasil

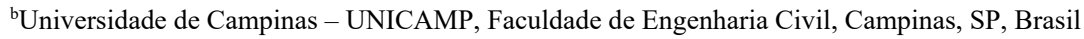

Received 23 March 2020

Accepted 25 May 2020

\begin{abstract}
In recent years, engineering has significantly increased the use of numerical modeling, mainly applied in studies of solutions and analysis of the behavior of the soil - structure and foundation element interaction. In this sense, this paper analyzes the behavior of blocks foundations made up of one, two, three and four piles with $25 \mathrm{~cm}$ in diameter (d) and $5 \mathrm{~m}$ in length (L) and with unusual spacing between the piles, equal to $5 \mathrm{~d}$ in a three-dimensional finite element numerical model (MEF-3D). The results of the numerical analyzes demonstrated an average contribution of $36 \%$ due to the block-to-ground contact in relation to the total capacity of the system. The geometry of the block influences the response in terms of load capacity and stiffness of the foundation element. These results demonstrate an opportunity to reevaluate traditional calculation requirements, with the aim of rationalizing the design of foundations, thus improving the safety of the structural system.
\end{abstract}

Keywords: numerical analysis, block geometry, load-settlement curve, piled raft.

\begin{abstract}
Resumo: Nos últimos anos, a engenharia tem aumentado significativamente o uso da modelagem numérica, principalmente aplicada em estudos de soluções e análise do comportamento da interação solo - estrutura e elemento de fundação. Nesse sentido, este trabalho analisa o comportamento de fundações de blocos constituídos por uma, duas, três e quatro estacas com $25 \mathrm{~cm}$ de diâmetro (d) e $5 \mathrm{~m}$ de comprimento (L) e com espaçamentos não usuais entre as estacas, igual a $5 \mathrm{~d}$ em um modelo numérico de elemento finito tridimensional (MEF-3D). Os resultados das análises numéricas demonstraram uma contribuição média de $36 \%$ devido ao contato bloco-solo em relação à capacidade total do sistema. A geometria do bloco influencia a resposta em termos de capacidade de carga e rigidez do elemento de fundação. Estes resultados demonstram uma oportunidade de reavaliar os requisitos tradicionais de cálculo, com o objetivo de racionalizar o dimensionamento das fundações, melhorando assim a segurança do sistema estrutural.
\end{abstract}

Palavras-chave: análise numérica, geometria do bloco, curva carga vs recalque, radier estaqueado.

How to cite: J. R. Garcia and P. J. R. Albuquerque, "Numerical analysis of the influence of block geometry on the behavior of piled foundations," Rev. IBRACON Estrut. Mater., vol. 14, no. 1, e14107, 2021, https://doi.org/10.1590/S1983-41952021000100007

\section{INTRODUCTION}

The first studies that considered the contribution of the support capacity arising from the liquid area, between the piles, in piled foundations occurred in the 1950s, from the studies developed by Zeevart [1], Katzenbach and Reul [2], Burland et al. [3], Davis and Poulos [4]. The study of Katzenbach and Reul [2] is considered as one of the first to consider the contact of the piled foundation in the ground. Piled foundations contribute significantly to normalizing settlements [5], increasing the load capacity of the system and improving efficiency when compared to traditional foundations [6]-[9] in addition to reducing costs associated with the foundation [10]. Optimization occurs by reducing 
the required number of piles when the block contributes to this additional capacity [8], [5]. However, for a long time the contribution of the shallow foundation surface close to the soil was neglected, regardless of whether the block was in contact with the soil or not.

One of the main benefits of the contact block is to avoid the collapse of this foundation system., i.e., this contact causes an increase in the horizontal stress acting on the pile shaft, concomitantly with the stress effect caused by its action close to the ground [11]-[13]. The capacity gain of an unpiled and piled raft foundation was linearly dependent on the load distribution when embedded in a uniform soil [14]. The magnitude of the spacing influences greatly the development of the behavior of piled foundations (piled raft). According to Brand et al. [15] and Koizumi and Ito [16], the influence of the block is only significant for blocks with sufficiently spaced piles, from a spacing of three times the diameter of the piles, making the block-ground contact support about $20 \%$ of the ultimate load.

It is common for conventional foundation designs to consider that the entire design load is assumed by the piles, thus neglecting the contribution of the block-to-ground contact [7]. This traditional design approach (design approach based on load capacity, CBD) conflicts with the experimental results obtained by several authors [17]-[21]. For groups of piles with a small proportion of s/d spacing ( $~ 3$ to 4$)$ and which cover the entire block area, the percentage of the load supported by the block is not less than approximately $20 \%$, and this value increases up to $60-70 \%$ with the increase in the s/d ratio [21].

There are several interactions that govern the behavior of pile foundations, such as those of (Figure 1): group dimensions, subsoil conditions, the method of installing the piles, the level of stresses applied, among other factors [22].

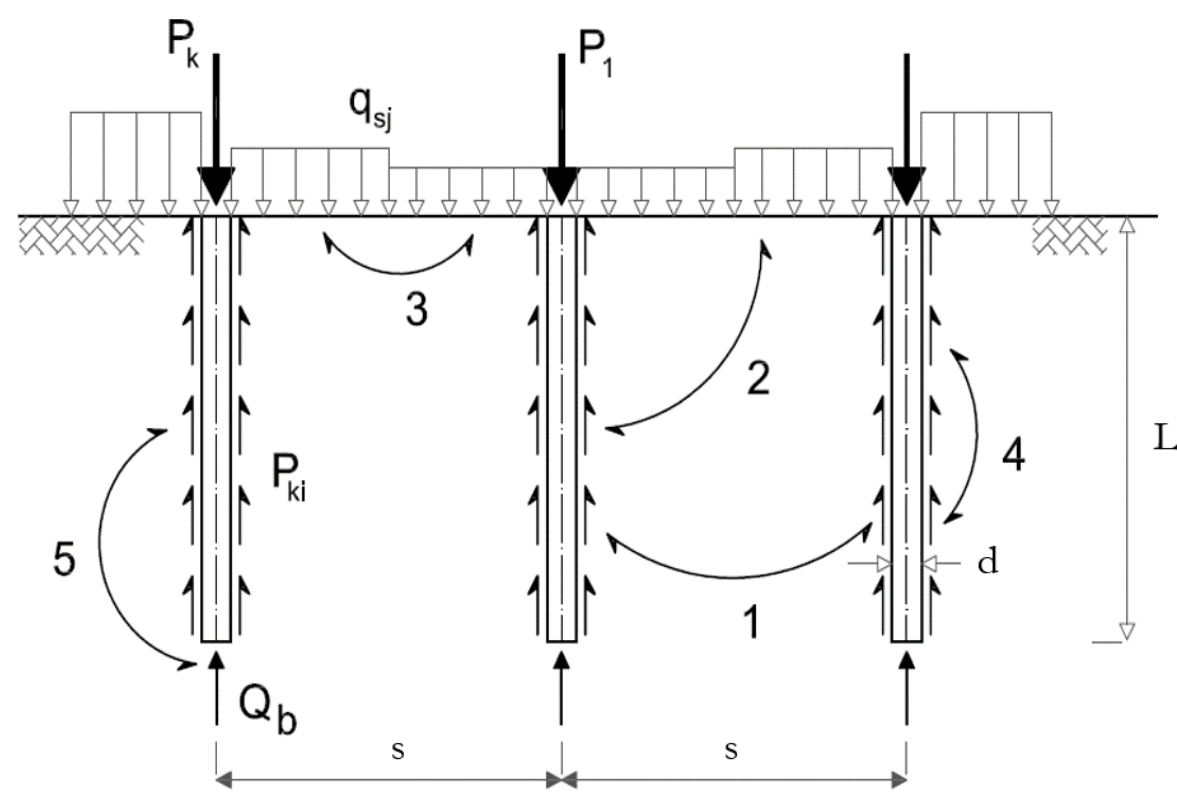

Figure 1. Different interactions that affect piled raft behavior [22]

Papers on the analysis of piled foundations using numerical models, based on three-dimensional finite elements [17], [23]-[25], can be found in the literature. The methods for analyzing the behavior of piled foundations are complex due to the large number of factors involved in the soil-pile block interaction [7] and [26].

\section{STRUCTURAL AND GEOTECHNICAL CHARACTERIZATION}

All the properties of the soil layers were obtained through in-situ and laboratory tests, as well as for the concrete of the piles and blocks (Figure 2 and Table 1). These parameters used of this study was obtained at Unicamp Experimental Site II, located the School of Civil Engineering, Architecture and Urban Planning (FEC) at Unicamp, Campinas, SP, Brazil. The crowning blocks were simulated with a height that results in a strut inclination angle between $40^{\circ}$ and $55^{\circ}$, that is, rigid block (Figure 3). 


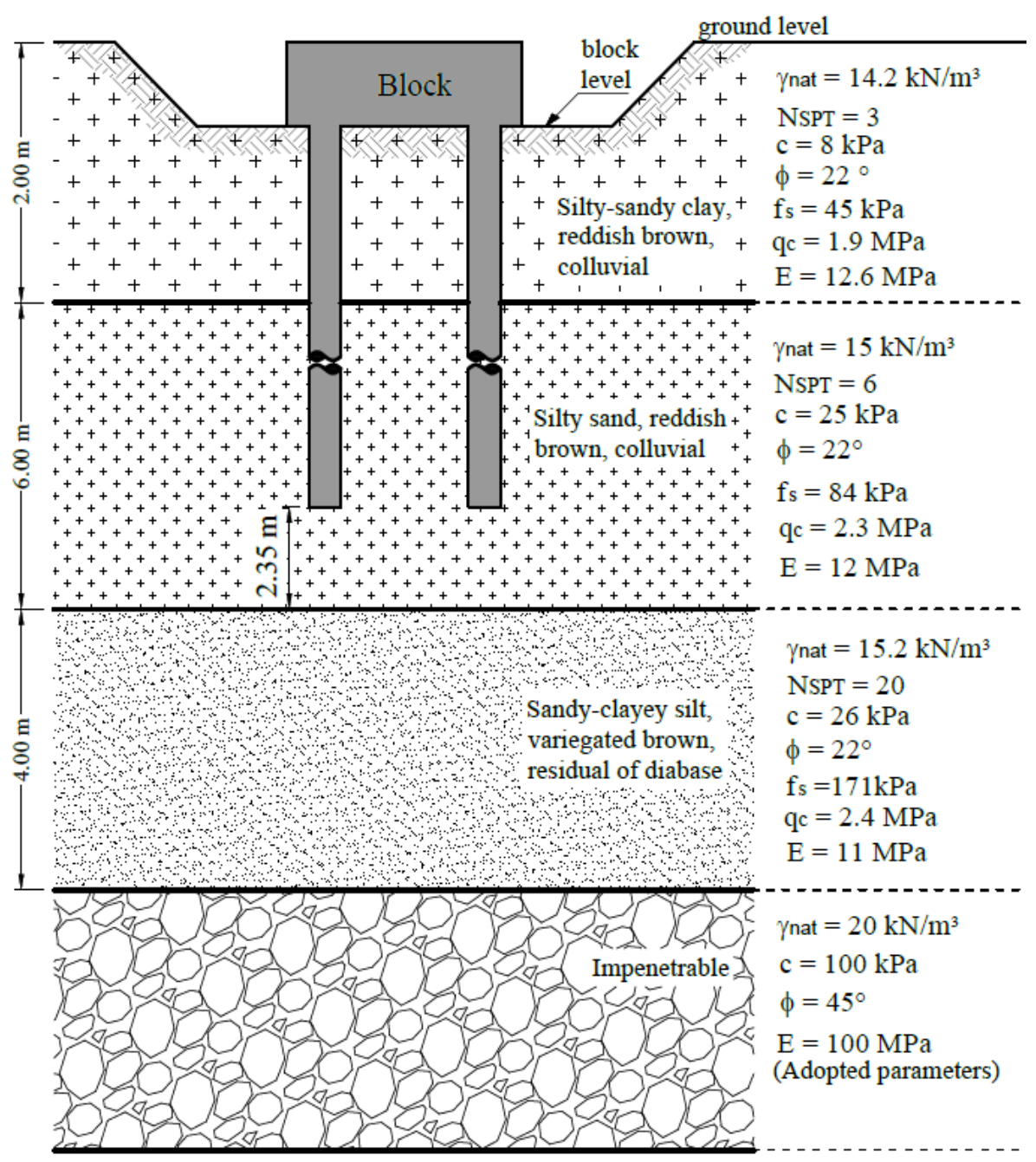

Figure 2. Geological-geotechnical profile and position of the piled foundations, modified from Garcia and Albuquerque [27]: $\gamma_{\text {nat }}$ - Unit weight; NSPT - Blow of SPT test; c - Cohesion; $\phi$ - Friction angle; fs - Sleeve friction; qc - Tip resistance; E - Young's modulus.

The Young's modulus obtained for both concrete and steel were used to estimate the composite modulus.

$$
E_{\text {composite }}=\frac{A_{a} \cdot E_{a}+A_{c} \cdot E_{c}}{A_{a}+A_{c}}
$$

$A_{a}-$ Useful cross-sectional area of steel; $E_{a}-$ Young's modulus of steel $\left(\mathrm{MN} / \mathrm{m}^{2}\right) ; \mathrm{A}_{\mathrm{c}}-$ Useful cross- sectional area of concrete; $\mathrm{E}_{\mathrm{c}}-$ Young's modulus of concrete $\left(\mathrm{MN} / \mathrm{m}^{2}\right)$.

Table 1. Strength and strain parameters of concrete

\begin{tabular}{|c|c|c|c|c|c|}
\hline \multirow{2}{*}{ Material } & $\mathbf{E}$ & $\gamma$ & $\mathbf{R}_{\mathbf{c}}$ & $\mathbf{R}_{\mathbf{t}}$ & $v$ \\
\hline & [MPa] & {$\left[\mathrm{kN} / \mathbf{m}^{3}\right]$} & [MPa] & [MPa] & {$[-]$} \\
\hline Concrete & 25,000 & 25.0 & 36.7 & 3.67 & 0.2 \\
\hline
\end{tabular}

$\mathrm{R}_{\mathrm{c}}$ : Compression strength; $\mathrm{R}_{\mathrm{t}}$ : Tensile strength; E: Young's Modulus 
Piled foundations - Block with piles * dimensions in meters
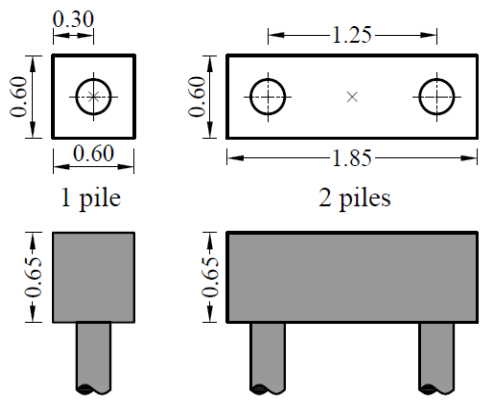
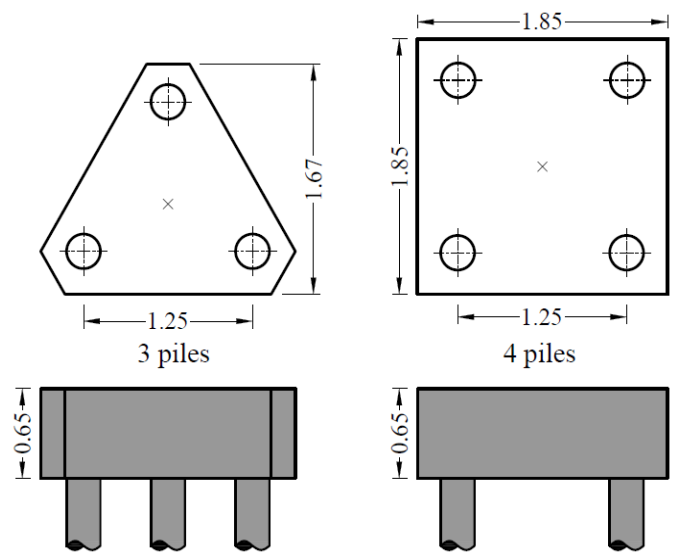

Figure 3. Plan view and elevation details of piled foundations [27]

\section{NUMERICAL MODELING}

The numerical model of the piled foundations analyzed was made from a quarter $(1 / 4)$ of the problem, due to the existing symmetry for the foundations composed of one, two, three and four piles (Figure 4, Figure 5, Figure 6 and Figure 7). For the analysis of the foundation made up of three piles, the constructed model represents half $(1 / 2)$ of the problem (Figure 6).



Figure 4. Perspective of the finite element mesh of the piled foundation with one pile [10]



Figure 5. Perspective of the finite element mesh of the piled foundation with two piles [10] 


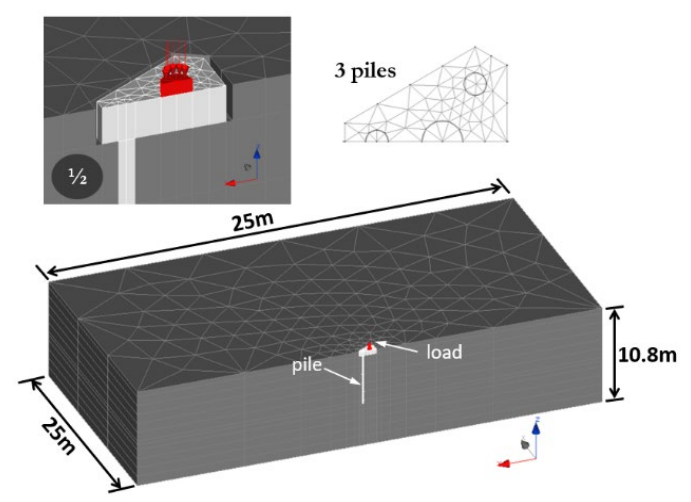

Figure 6. Perspective of the finite element mesh of the piled foundation with three piles [10]

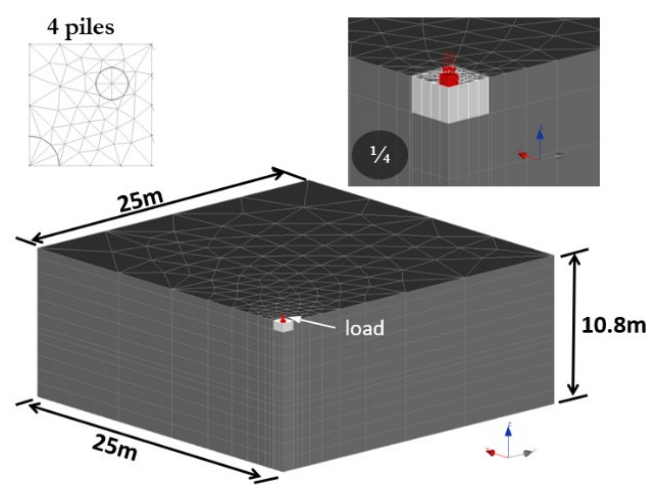

Figure 7. Perspective of the finite element mesh of the piled foundation with four piles [10]

The boundary conditions attributed to the model are important factors observed in several studies [28]-[32], among others. The dimensions adopted for the numerical model were assigned in order to ensure that the boundary conditions at the ends of the problem resulted in zero displacement, consequently, they did not affect the results of the analyzes with the foundation and soil element. Therefore, the limits of the numerical model were defined to minimize the influence of stresses on the limits of the problem. The sides of the model were fixed for horizontal movement $(\mathrm{dx}=0)$ and kept free in the vertical direction. The lower limit of the model was fixed against vertical and horizontal movements $(\mathrm{dx}=\mathrm{dy}=0)$. Therefore, the geometry of the model was determined by means of convergence tests, which involve verifying whether the responses of the boundary conditions are in accordance with the boundary limits defined in the pre-processing step.

\subsection{Constitutive model}

The finite element mesh is composed of triangular elements of quadratic interpolation, which were extruded every meter in depth, resulting in a volumetric element of the pentahedral type composed of 15 nodes. Numerical analyzes were performed using the software LCPC-CESAR v.5.04, developed at the Laboratoire Central des Ponts et Chaussées. This software is a 3D Finite Element Method tool. The Mohr -Coulomb model, perfectly elastic-plastic, was used to simulate the nonlinear behavior of the soil in terms of stress-strain and adopted failure criteria: unit weight $(\gamma)$; cohesion (c); friction angle $(\phi)$; Young's modulus (E) and Poisson's ratio (v). These parameters had been previously obtained by Gon [33], except for Poisson's ratio, which was adopted because of the soil behavior as assessed by the tests. For materials with brittle behavior, a linear elastic parabolic model was used, i.e., concrete of the piles and raft/block. These parameters were determined in the laboratory by Garcia [10], such as compression strength $\left(R_{c}\right), E_{c}$ and $v_{c}$, and values for tensile strength $\left(\mathrm{R}_{\mathrm{t}}=10 \% \cdot \mathrm{R}_{\mathrm{c}}\right)$ and $\gamma_{\mathrm{c}}$. 


\subsection{Convergence test}

The convergence test, which consists of verifying whether the boundary conditions provide results that are in accordance with the pre-established definitions, was performed in the preprocessing step to validate the half-space dimensions, i.e., the model geometry. Comparisons with available results were made to ensure the applicability of the program to the problems addressed in this study.

The dimensions of the model and the respective number of nodes and elements were checked. The evaluated geometries were: $10 \times 10 \mathrm{~m}^{2}, 15 \times 15 \mathrm{~m}^{2}, 20 \times 20 \mathrm{~m}^{2}$ and $25 \times 25 \mathrm{~m}^{2}$. The boundary conditions imposed by the problem

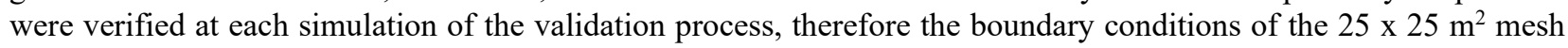
showed deformations of less than one tenth of a millimeter, as such these were considered insignificant for the type of problem under analysis.

The convergence tests resulted in a "block/raft" measuring $25 \times 25 \mathrm{~m}^{2}$ and $10.8 \mathrm{~m}$ deep. An elastoplastic model was used that varies according to the applied stresses, and thus follows a non-linear behavior.

The problem composition resulted (on average) in a finite element mesh comprising of 6,500 elements and 20,000 nodes.

In addition, analyzes were carried out to validate the model, tests of finite element mesh refinement. Thus, we analyzed the responses to the displacement at the edge compared to other forms of refinement, with lower density in terms of elements and nodes.

The refinement of the mesh, by increasing the density of the mesh of finite elements, caused the initially obtained displacement to increase in the successive stages until they were practically stable in the 3rd stage. Therefore, the option was to maintain the mesh with the same number of elements and nodes as in the previous phase (2nd stage), as there would be no improvement through further refinement of this mesh.

To ensure the reliability of the numerical analysis results, verifications have been performed before initiating the analyses: comparison with available published results, convergence test to ensure that the boundary conditions did not influence the analysis results and comparison of the soil parameters used in the analysis with the experimental results.

After completing the steps, the finite element model was calibrated by comparing the results of a load test on a single pile $(\mathrm{L}=5 \mathrm{~m}$ and $\phi=0.25 \mathrm{~m})$ that was evaluated by Schulze [34] at the FEC-Unicamp experimental site for the same pile, using the properly adjusted soil parameters that were originally obtained by Gon [33]. The numerical analyses performed in this study were subdivided into two stages. The first stage was the calibration of the geotechnical parameters in the Mohr-Coulomb constitutive model. The second stage a comprised numerical analysis of the piled rafts.

\section{RESULTS AND DISCUSSIONS}

From the numerical simulations, load vs settlement curves of the piled foundations analyzed in this paper were obtained by use of the previously calibrated model (Figure 8). The behavior of the curves does not demonstrate the occurrence of failure of the foundation system. This is due to the contact effect of the block on the ground, which the behavior of this foundation to approach that of a shallow foundation, where failure is difficult to ascertain. In these cases, it is necessary to agree on the load failure, in order to obtain the allowable load that can be used in the design of foundations or in the verification of the supporting capacity of the foundation element in relation to the safety of the structure. In this aspect, the evaluation can be made of the degradation of the safety factor in relation to the maximum load (Qmax), in such a way that displacement caused by the load of the respective stage and the resulting safety factor of this design condition can be evaluated together (Figure 9). In this type of result evaluation, displacement (settlement) tends to be the limiting factor in establishing the allowable design load, which depends on the characteristics of the superstructure.

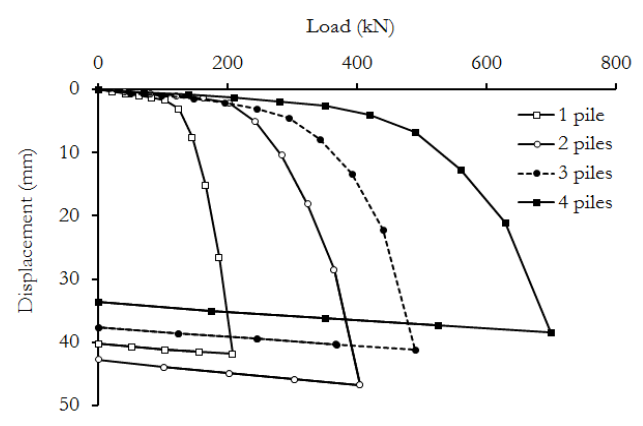

Figure 8. Results for load-displacement curve of piled foundations. 


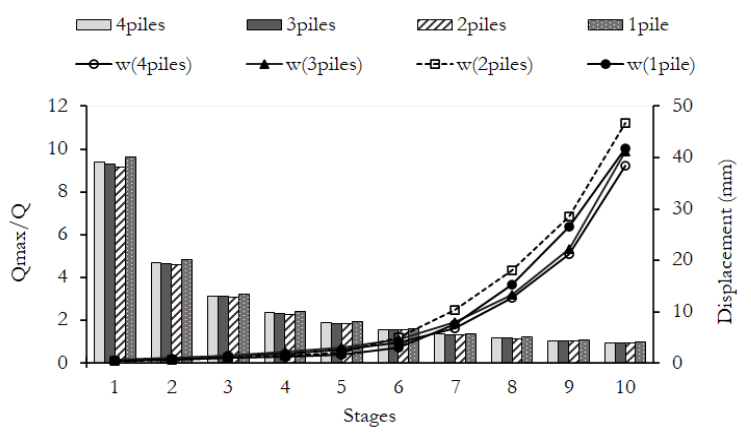

Figure 9. Variation of the Qmax/Q relationship by stage increment and displacement.

The ultimate load was then established by well-known criteria, the Van der Veen [35] method, the stiffness method [36] and the Eurocode criterion. The results of the load vs settlement curve for each of the numerically tested foundations were reprocessed by each of the methods mentioned, so that each of these methods generated a curve through retroanalysis. For the blocks of one pile, it was found that there existed less agreement between the curves in relation to the other pile blocks (Figure 10), since this type of foundation approaches the behavior of an isolated pile, due to the small net area of block-contact with the ground. The results of this analysis demonstrate that there is good agreement between the numerical results and those obtained by the Van der Veen and the stiffness method, mainly for blocks composed of two, three and four piles (Figure 11, Figure 12 and Figure 13).

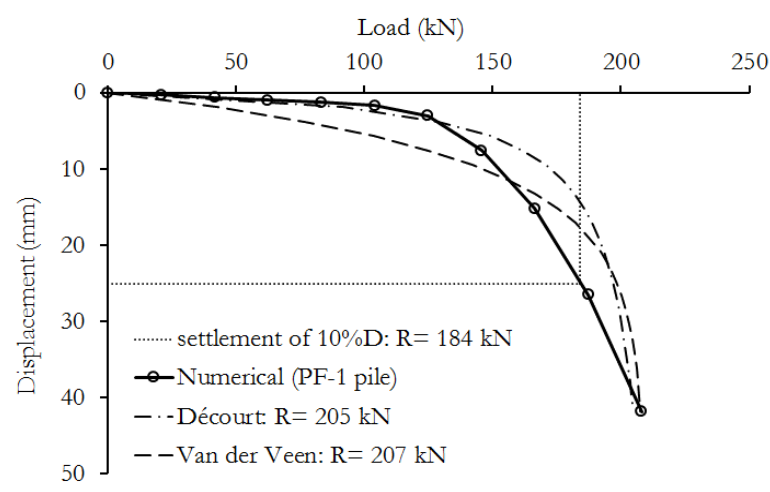

Figure 10. Extrapolation of the curve for the piled foundation using one pile.

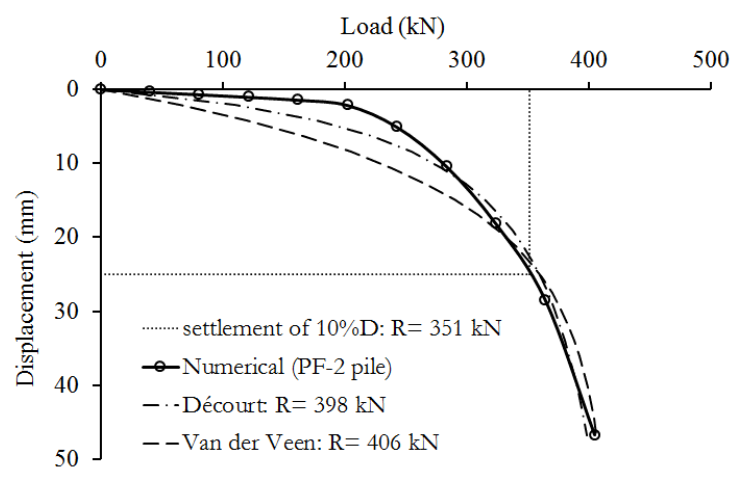

Figure 11. Extrapolation of the curve for the piled foundation using two piles. 


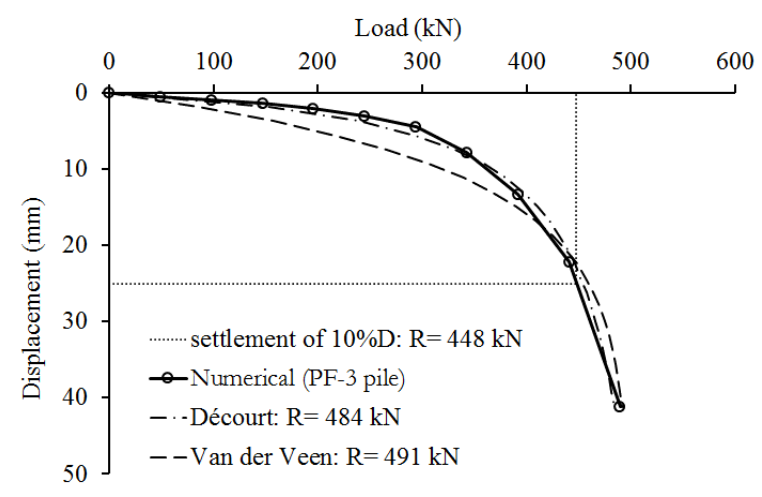

Figure 12. Extrapolation of the curve for the piled foundation using three piles.

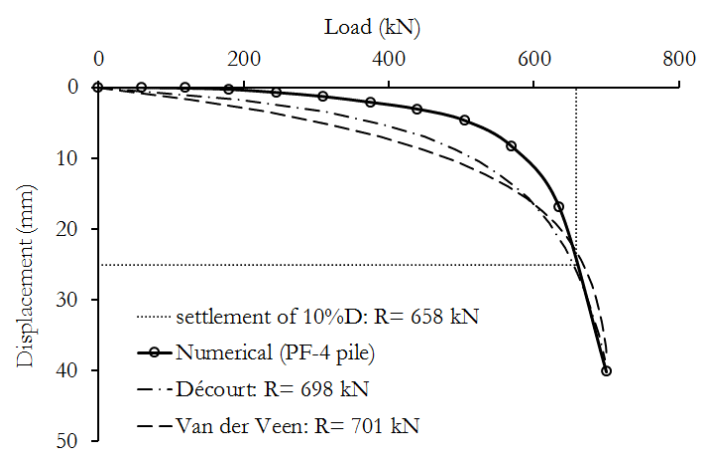

Figure 13. Extrapolation of the curve for the piled foundation using four piles.

Once the ultimate load was decided, due to the different extrapolation and displacement fixation criteria, the allowable load (for a safety factor of two [37]) of the pile foundations was obtained, consisting of one, two, three and four piles (Table 2).

Table 2. Extrapolated failure load (R), maximum settlement load ( $\left.\mathrm{P}_{\max }\right)$, load corresponding to the $10 \%$ settlement $\phi\left(\mathrm{P}_{10} \%\right)$ and allowable foundation loads $(\mathrm{Pal})$ via distinct failure criteria.

\begin{tabular}{|c|c|c|c|c|c|c|}
\hline \multirow{2}{*}{ Piled Foundation } & \multicolumn{2}{|c|}{ Van der Veen } & \multicolumn{2}{|c|}{ Stiffness (Décourt) } & \multicolumn{2}{|c|}{$10 \% \cdot \phi($ Eurocode $)$} \\
\hline & $\mathbf{R}(\mathrm{kN})$ & $\mathbf{P}_{\mathrm{al}}(\mathrm{kN})$ & $\mathrm{R}(\mathrm{kN})$ & $P_{\mathrm{al}}(\mathrm{kN})$ & $P_{10 \%}(k N)$ & $\mathbf{P}_{\mathrm{al}}(\mathrm{kN})$ \\
\hline 1 pile & 207 & 103.5 & 205 & 102.5 & 184 & 92.0 \\
\hline 2 piles & 406 & 203.0 & 398 & 199.0 & 351 & 175.5 \\
\hline 3 piles & 491 & 245.5 & 484 & 242.0 & 448 & 224.0 \\
\hline 4 piles & 701 & 350.5 & 698 & 349.0 & 658 & 329.0 \\
\hline
\end{tabular}

Although it is fundamental to understand the behavior of the foundation system, it is equally important to understand how load distribution occurs, since the behavior of foundations supported on piles and soil is analyzed. Therefore, the loads absorbed at the top of the piles in each foundation system were determined (Figure 14 and Figure 15). This compression measure was performed considering the average from a total of 16 points distributed in the cross section of each pile. Thus, it was possible to determine the load distribution between the surface and deep foundation elements, i.e., the load absorbed by the pile or pile group and the block-to-ground contact at each loading stage. 


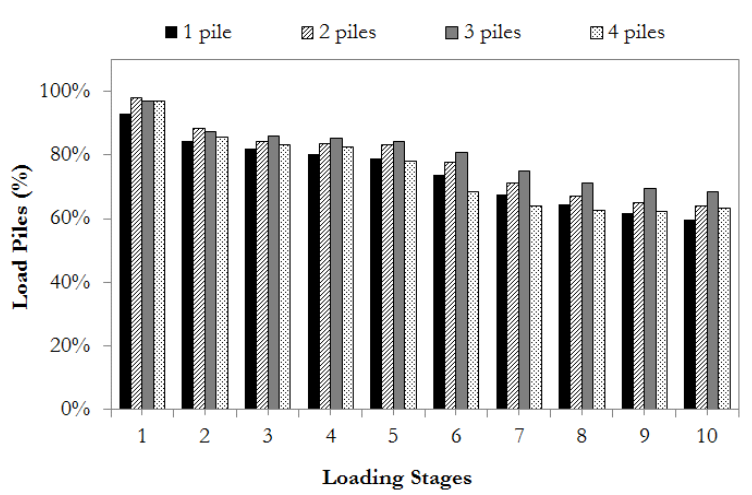

Figure 14. Load born by piles.

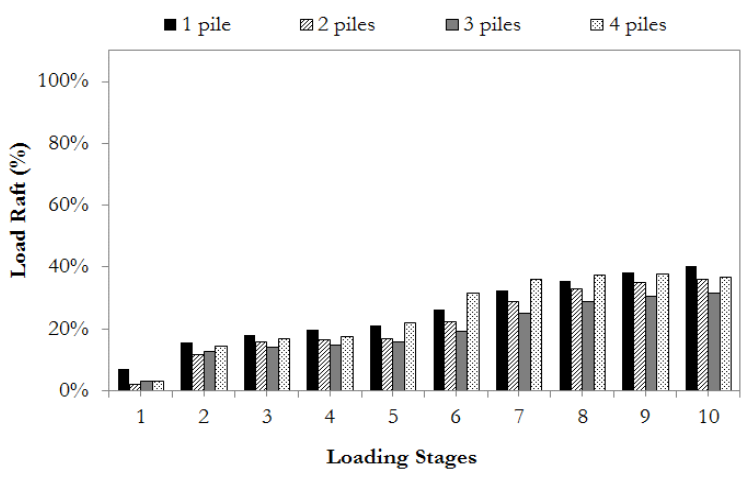

Figure 15. Load born by the shallow element.

The average load mobilized by the piles of the triangular block of three piles, is higher in practically all loading stages, mainly from the sixth loading stage, predominating up to the maximum test load (Figure 14). The increased compression of the block-to-ground contact does not seem to be as effective, due to its triangular geometry, and thus, a greater portion of load is observed acting on the piles. In blocks composed of two and four piles, there is a tendency toward an average load behavior in the piles, which remains more significant until the eighth stage, losing intensity until it is equalized in the maximum loading stage. On the other hand, the opposite behavior is observed for the average load that is absorbed by the block-ground contact, in which the three-pile block is the one with the lowest participation (Figure 15).

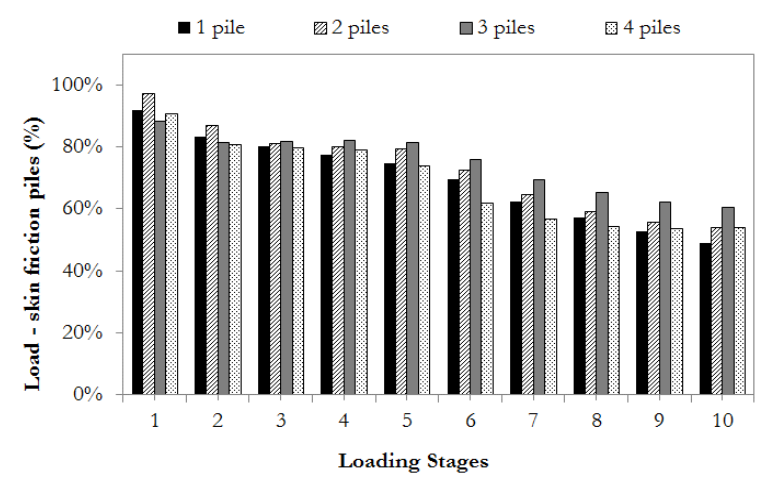

Figure 16. Load born by the skin friction. 




Figure 17. Load born by the tip of piles.

Through the transfer of the load from the top to the tip of the pile (Figure 16 and Figure 17), one notes that for blocks containing a group of piles, these somehow confine the soil between themselves (three and four piles). These also tend to mobilize greater tip resistance from the first stages of loading, which decreases until reaching the allowable load and then initiates an increase that continues until the maximum test load. The blocks of one and two piles, have low tip resistance in the first stages that gradually increases until the maximum test load. In all pile blocks, the skin friction resistance of the piles is higher in the first stages and decreases continuously with the increase of the tip resistance (Figure 17).

The difference in behavior of the foundation systems analyzed in this paper, may have been influenced by several factors, such as: the geometry of the block in contact with the underlying soil and the arrangement of the pile group (Figure 3). This could be explained by analyzing the initial stiffness of the load vs displacement curves separately. (Figure 18 to Figure 21). This seems to be related to the irregular geometry of the triangular block in contact with the ground, causing the increase in stresses not uniformly under the block, as well as in the other blocks.

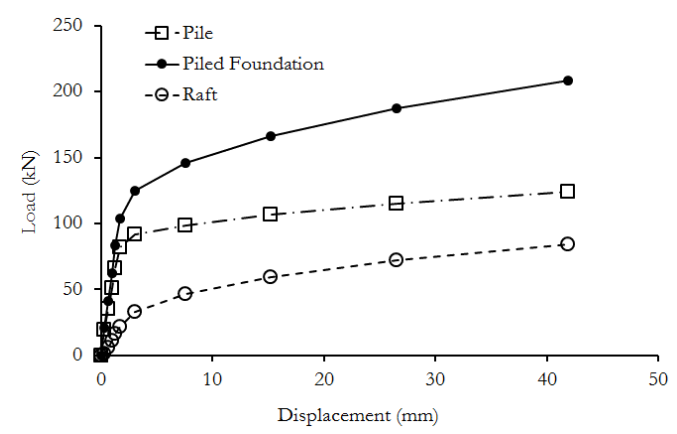

Figure 18. Load-displacement curve of piled foundation using one pile.



Figure 19. Load-displacement curve of piled foundation using two piles. 
The stiffness of the piled foundation and the respective foundation elements (piles and block) were determined from the initial tangent of its load vs settlement curves (Table 3 ).

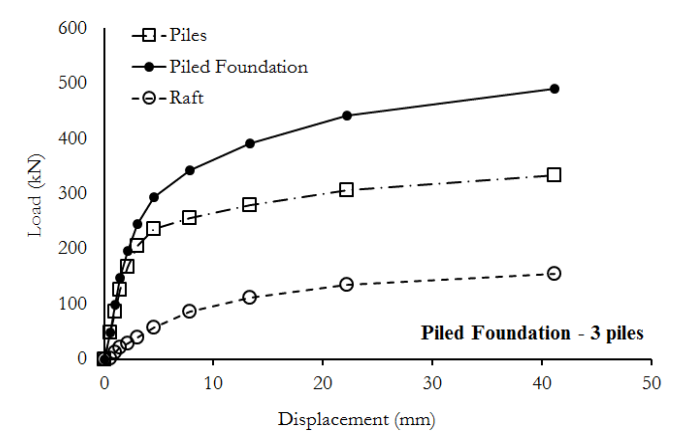

Figure 20. Load-displacement curve of piled foundation using three piles.

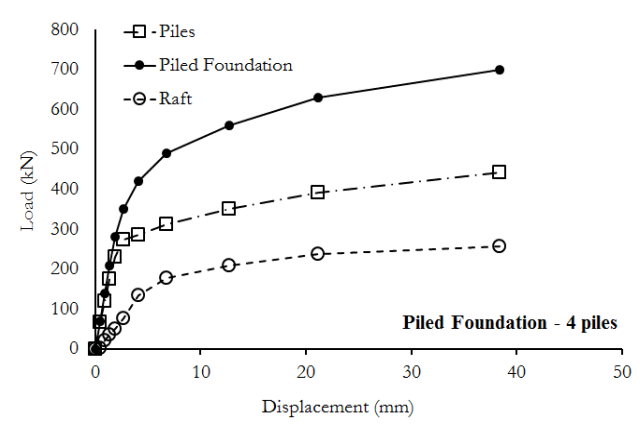

Figure 21. Load-displacement curve of piled foundation using four piles.

The obtained values of stiffness are higher for the foundation systems (piled foundation) in relation to the isolated elements (piles and blocks). The geometry of the surface foundation element (block) significantly influences the stiffness results, where the block composed of a pile is predominantly influenced by the pile stiffness and is very small when compared to the block, since its net area of block-soil contact is insignificant (Table 3). Similar behavior is observed in the block of four piles, where the stiffness of piles also predominates in relation to the block. In the case of two piles, the opposite occurs, since the block stiffness is greater than that of the piles, which may be justified by the resistant moment of this block. The block composed of three piles is the one that presents the most discrepant behavior in relation to the others and even though it is composed of several piles, the values of piles and block stiffness are low, as well as the system stiffness (Table 3). Regarding the stiffness of the foundation systems, there is a tendency to increase with the increase in the number of piles and the geometry of the block for all cases, except for the block containing three piles that do not follow this trend (Table 3 and Figure 22).

Table 3. Stiffness of piles $\left(K_{p}\right)$, rafts $\left(K_{r}\right)$ and piled foundations $\left(K_{p r}\right)$.

\begin{tabular}{|c|c|c|c|}
\hline Piled Foundation & $K_{P}(k N / m m)$ & $K_{R}(\mathrm{kN} / \mathbf{m m})$ & $K_{P R}(\mathrm{kN} / \mathrm{mm})$ \\
\hline 1 pile & 87 & 2 & 87 \\
\hline 2 piles & 90 & 142 & 169 \\
\hline 3 piles & 42 & 34 & 104 \\
\hline 4 piles & 116 & 69 & 283 \\
\hline
\end{tabular}

From the results of the stiffness for the foundation system and the elements individually, trend lines were generated to find an equation that describes the behavior for the analyzed cases (Figure 22). From this analysis, we obtained the equations that describe the stiffness behavior of these foundations and their respective values of the determination 
coefficient $\left(\mathrm{R}^{2}\right)$, as presented on Table 4. In this analysis, the block composed of three piles showed the greatest discrepancy among all the cases analyzed, this is quite possibly due to the influence of the geometry of the block.

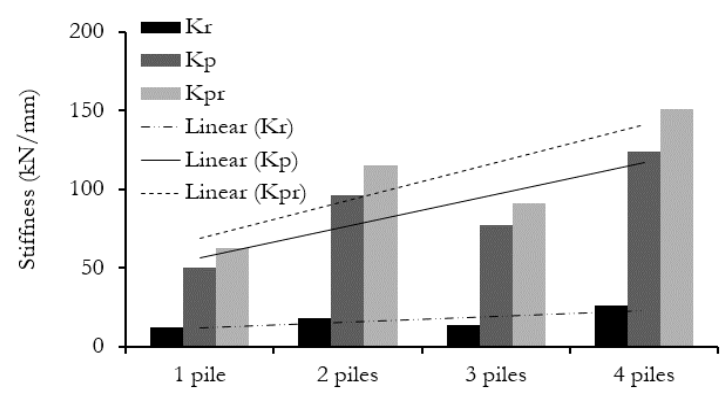

Figure 22. Results of stiffness for piles (Kp), rafts (Kr) and piled foundations (Kpr).

When analyzing the stiffness results in a scenario with all piled foundations and removing the triangular shaped block, it is found that the equations start to represent, in a more adequate manner, the behavior due to the increase in the number of piles, since the $\mathrm{R}^{2}$ values increase significantly, remaining above 0.90 for blocks composed of 1,2 and 4 piles (Table 4 ).

Table 4. Stiffness of piles $\left(\mathrm{K}_{\mathrm{p}}\right)$, rafts $\left(\mathrm{K}_{\mathrm{r}}\right)$ and piled rafts $\left(\mathrm{K}_{\mathrm{pr}}\right)$ depending on the number of piles.

\begin{tabular}{ccccc}
\hline Stiffness* & \multicolumn{2}{c}{ Piled foundation of 1, 2, 3 and 4 piles } & \multicolumn{2}{c}{ Piled foundation of 1, 2, and 4 piles } \\
\hline Raft & $\mathrm{K}_{\mathrm{r}}=3.8 \cdot \mathrm{n}+8$ & $\mathrm{R}^{2}=0.63$ & $\mathrm{~K}_{\mathrm{r}}=4.6 \cdot \mathrm{n}+8$ & $\mathrm{R}^{2}=0.99$ \\
\hline Pile(s) & $\mathrm{K}_{\mathrm{p}}=20.3 \cdot \mathrm{n}+36$ & $\mathrm{R}^{2}=0.71$ & $\mathrm{~K}_{\mathrm{p}}=23.1 \cdot \mathrm{n}+36$ & $\mathrm{R}^{2}=0.90$ \\
\hline Piled Raft & $\mathrm{K}_{\mathrm{pr}}=24 \cdot \mathrm{n}+45$ & $\mathrm{R}^{2}=0.69$ & $\mathrm{~K}_{\mathrm{pr}}=27.7 \cdot \mathrm{n}+45$ & $\mathrm{R}^{2}=0.92$ \\
\hline
\end{tabular}

Where $\mathrm{n}$ is the number of piles. *Values for guidance only, due to the small number of results.

For the adequate foundation design, it is necessary to establish the displacement that the structure may be subjected to, in order that the allowable settlement is the factor that determines the allowable design load, since the allowable load obtained for a safety factor restricts travel to levels acceptable by the superstructure. When analyzing the relationship between normalized displacement (w/D) and normalized load (Qmax/Q), it appears that for all piled foundations, limiting the settlement between $5 \%$ and $10 \%$ of the pile diameter, the maximum load which would define the permissible design load, is in the range between 0.73 and 0.93 . This confirms that the foundation design must be carried out through the control of settlement and not by the load capacity (as noted by [5], [38], [8], [4]), as is usually the case (Figure 23). In an analysis in terms of the safety factor $(\approx$ Qmáx/Q), it appears that this reduces from 2 to 1 for a settlement between $5 \%$ and $10 \%$ of the pile diameter, proving that the loss of safety and stability of the pile superstructure by the foundation support occurs for low displacement levels (Figure 23).

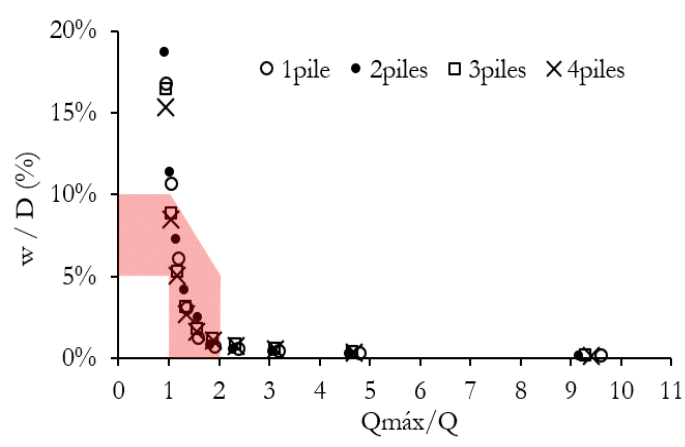

Figure 23. Mean normalized displacement and normalized load of the piled foundations. 
The participation of piles in the load capacity of the piled foundation showed that the interaction factor $\left(\alpha_{\mathrm{pr}}\right)$, influenced the load transfer model in the cases analyzed, either by the geometry of the block-ground contact or due to the magnitude of this area (Figure 24). The Figure 25, it is possible to evaluate the variation of the $\alpha_{\mathrm{PR}}$ according to the loading evolution.

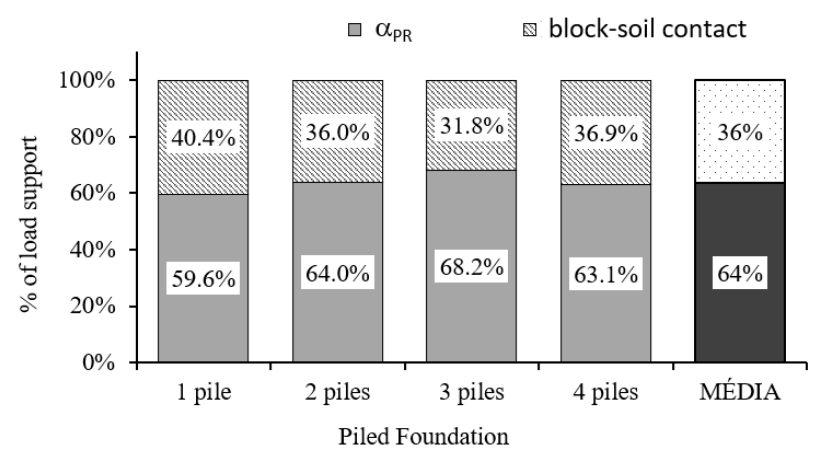

Figure 24. Contribution of piles group ( $\alpha \mathrm{PR})$ and raft-soil contact.

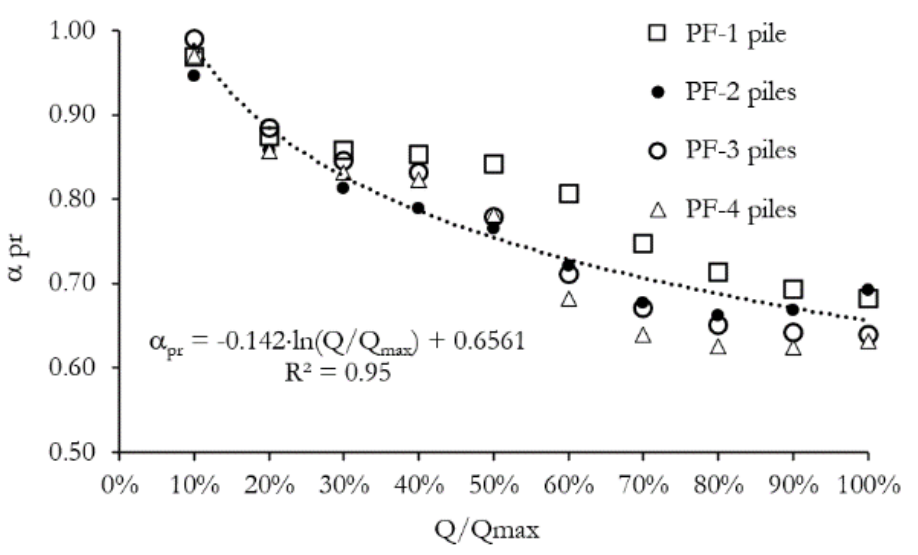

Figure 25. Variation of $\alpha_{P R}$ and $Q / Q_{\max }$.

The highest value of the observed interaction factor occurred in the pile block composed of three piles (68.2\%), and the lowest, for the piled foundation composed of 1 pile (59.6\%), with an overall average of $64 \%$. The participation due to the block-to-ground contact was $36 \%$, a value close to those observed in some works in the literature (Figure 24), as verified by Mandolini et al. [21].

The pile contribution to the load capacity of the piled raft can be seen in Figure 25. It is noted that at the beginning of the loading $(\mathrm{Q} / \mathrm{Qmax}=10 \%)$ the piles were responsible for receiving the entire load. During the loading, the raft increases to contribute to the load capacity, ending with an average of $36 \%$ (Figure 24). When the applied load represented half of the applied load $(\mathrm{Q} / \mathrm{Qmax}=50 \%)$, the raft was responsible, on average, for $25 \%$ of the load. In general, this effect is disregarded in foundation design, which can be interesting when evaluating the performance of the foundation in the structure. According to Brand et al. [15] and Koizumi and Ito [16], the influence of the block is only significant for blocks with sufficiently spaced piles, from a spacing of three times the diameter of the piles, making the block-ground contact support about $20 \%$ of the ultimate load.

\section{CONCLUSIONS}

Considering the analyses and discussions of this study, the following conclusions can be drawn:

The consideration of the block-to-ground contact effect can optimize the design of foundations with significantly positive impacts technically and economically, as the application of this technique allows one to take advantage of the 
availability of the surface resistance of the soil adjacent to the block and between the group of piles, promoting greater stability and security of the structure.

Regarding the load capacity, it was found that the greatest relative difference occurred when analyzing the ultimate load given from ratio between the block composed by one pile and two piles, which showed an increase in strength of the order of $100 \%$. Evaluating the ratio with blocks of three and four piles, there was an increase of $150 \%$ and $250 \%$, respectively. In these sets, there is no direct relationship between ultimate load and number of piles in the block.

The modeling demonstrated that the contact effect in piled rafts, with pile spacing equal to $5 \phi$ of average net area, accounts for $36 \%$ of the ultimate load applied to the piled raft, compared to $64 \%$ due pile load.

In the ultimate load, the piles showed frictional behavior with a tip load of around $10 \%$. Behavior already expected in view of the subsoil resistance along the depth.

The stiffness of piled foundations must be analyzed from the perspective of reduced settlement values that the structure can support. It is also suggested which consideration, when designing the foundations, is given to the stiffness obtained by the initial tangent of the characteristic curves of these foundations. The suitable range for analyzing the capacity of the foundation system should be between $5 \%$ and $10 \%$ of the pile diameter.

The stiffness retroanalysis showed a good approximation considering all the cases analyzed (one pile, two piles, three piles and four piles) in this paper and according to the characteristics considered. When considering only piled foundations composed of 1 pile, 2 piles and 4 piles, the retroanalysis showed significantly important results with $\mathrm{R}^{2}$ above 0.9. However, the correlations presented in Table 4 was obtained for the foundation's geometry analyses (number of piles, diameter, length etc) and geotechnical profile for specific case this article.

\section{ACKNOWLEDGEMENTS}

The authors would like to thank the São Paulo Research Foundation (Fundação de Amparo à Pesquisa no Estado de São Paulo - FAPESP), the National Council for Scientific and Technological Development (Conselho Nacional de Desenvolvimento Científico e Tecnológico - CNPq) and the Foundation for Research and Extension Support (Fundação de Apoio à Pesquisa e Extensão - FAEPEX - Unicamp) for the financial support necessary for research development.

\section{CITATIONS}

[1] L. Zeevart, "Compensated friction-pile foundation to reduce the settlement of buildings on highly compressible volcanic clay of Mexico City," in Proc. 4th Int. Conf. Soil Mech. Found. Eng., 1957.

[2] R. Katzenbach and O. Reul, "Design and performance of piled rafts," in Proc. XIV Int. Conf. Soil Mech. Found. Eng., 1997, pp. 6-12.

[3] J. B. Burland, B. B. Broms, and V. F. B. De Mello, "Behaviour of foundations and structures," in Proc. IX ICSMFE, 1977, pp. 495545.

[4] E. H. Davis and H. G. Poulos, "Rate of settlement under two-and three-dimensional conditions," Geotechnique, vol. 22, no. 1, pp. 95114, Mar 1972.

[5] M. F. Randolph, "Design Methods for pile groups and pile rafts," in Proc. XIII Int. Conf. Soil Mech. Found. Eng., 1994, pp. 61-82.

[6] M. M. Sales, Behavior Analysis of Piled Rafts. Brasília: Civ. Environ. Eng. Dep., Univ. Brasilia, 2000.

[7] H. G. Poulos, "Piled raft foundations: design and applications," Geotechnique, vol. 51, no. 2, pp. 95-113, Mar 2001.

[8] J. E. Bezerra, "Estudo do comportamento de fundações em radier estaqueado: conceitos e aplicações,” M.S. thesis, Univ.Brasília, Brasília, 2003.

[9] P. Deb and S. K. Pal, "Analysis of load sharing response and prediction of interaction behaviour in piled raft foundation," Arab. J. Sci. Eng., vol. 44, no. 10, pp. 8527-8543, Oct 2019.

[10] J. R. Garcia, “Análise experimental e numérica de radiers estaqueados executados em solo da região de Campinas/SP,” Ph.D. dissertation, Univ. Est. Campinas, Campinas, 2015.

[11] L. Phung, "Piled raft - a cost-effective foundation method for high-rises," Geotech. Eng. J. SEAGS AGSSEA, vol. 41, pp. 1-12, 2010.

[12] M. Ottaviani, "Three-dimensional finite element analysis of vertically loaded pile groups," Geotechnique, vol. 25, no. 2, pp. 159-174, Jun 1975.

[13] L. Jinli and Y. Zhenlong, "“Comportement et problemes de calcul des groupes de pieux dans le limon,” Bull. Liaison Lab. Ponts Chaussees, vol. 3, no. 160, pp. 21-35, 1989.

[14] B. Sheil, "Numerical simulations of the reuse of piled raft foundations in clay," Acta Geotech., vol. 12, no. 5, pp. 1047-1059, Oct 2017.

[15] E. W. Brand, C. Muktabhant, and A. Taechathummarak, "Load tests on small foundation in soft clay," in ASCE Conf. Perform. Earth and Earth Support. Struct., 1972, pp. 903-928. 
[16] Y. Koizumi and K. Ito, "Field tests with regard to pile driving and bearing capacity of piled foundations," SOILS Found., vol. 7, no. 3, pp. 30-53, 1967.

[17] A. Mandolini, "Design of piled raft foundations: practice and development," in BAP IV, Int. Geotech. Semin. Deep Found. Bored and Auger Piles, 2003, pp. 59-80.

[18] G. Conte, A. Mandolini, and M. F. Randolph, "Centrifuge modelling to investigate the performance of piled rafts," in BAPIV, Int. Geotech. Semin. Deep Found. Bored and Auger Piles, 2003, pp. 359-366.

[19] C. Viggiani, A. Mandolini, and G. Russo, "Piles and pile groups," in Applied Soil Mechanics, J. A. Hemsley, Ed., 1st ed. Hoboken, NJ, USA: John Wiley \& Sons, 2012, pp. 286-331.

[20] L. De Sanctis and A. Mandolini, "Bearing capacity of piled rafts on soft clay soils," J. Geotech. Geoenviron. Eng., vol. 132, no. 12, pp. 1600-1610, 2006.

[21] A. Mandolini, R. Di Laora, and Y. Mascarucci, "Rational design of piled raft," Procedia Eng., vol. 57, pp. 45, 2013.

[22] Y. El-Mossallamy and E. Franke, "Piled rafts: numerical modelling to simulate the behaviour of piled raft foundations," in Design Applications of Raft Foundations, J. A. Hemsley, Ed., Darmstadt, Germany, 1997.

[23] L. de Sanctis and G. Russo, "Analysis and performance of piled rafts designed using innovative criteria," J. Geotech. Geoenviron. Eng., vol. 134, no. 8, pp. 1118-1128, Aug 2008.

[24] M. F. Randolph and O. Reul, "Piled rafts in overconsolidated clay: comparison of in situ measurements and numerical analyses," Geotechnique, vol. 53, no. 3, pp. 301-315, 2003.

[25] O. Reul and M. F. Randolph, "Design strategies for piled rafts subjected to nonuniform vertical loading," J. Geotech. Geoenviron. Eng., vol. 130, no. 1, pp. 1-13, Jan 2004.

[26] J. Lee, Y. Kim, and S. Jeong, "Three-dimensional analysis of bearing behavior of piled raft on soft clay," Comput. Geotech., vol. 37 , no. 1-2, pp. 103-114, Jan 2010.

[27] J. R. Garcia and P. J. R. Albuquerque, "Analysis of the contribution of the block-soil contact in piled foundations," Lat. Am. J. Solids Struct., vol. 16, no. 6, pp. e211, 2019.

[28] R. B. J. Brinkgreve, W. M. Swolfs, and E. Engine, Plaxis User's Manual. Rotterdam: Balkema, 2002.

[29] J. Cho, J.-H. Lee, S. Jeong, and J. Lee, "The settlement behavior of piled raft in clay soils," Ocean Eng., vol. 53, pp. 153-163, Oct 2012.

[30] A. Alnuaim, H. Naggar, and M. H. El Naggar, "Performance of piled-raft system under axial load," in Proc. 18th Int. Conf. Soil Mech. Geotech. Eng., 2013.

[31] B. El-Garhy, A. A. Galil, A. F. Youssef, and M. A. Raia, "Behavior of raft on settlement reducing piles: Experimental model study," J. Rock Mech. Geotech. Eng., vol. 5, no. 5, pp. 389-399, 2013.

[32] Z. M. Omeman, "Load sharing of piled-raft foundations in sand subjected to vertical loads," Ph.D. dissertation, Concordia University, Montreal, 2012.

[33] F. S. Gon, “Caracterização geotécnica através de ensaios de laboratório de um solo de diabásio da região de Campinas/SP,” M.S. thesis, Fac. Eng. Civ. Arquit. Urban., Univ. Est. Campinas, Campinas, 2011.

[34] T. Schulze, “Análise da capacidade de carga de estaca escavada instrumentada de pequeno diâmetro por meio de métodos semiempíricos,” M.S. thesis, Univ. Est. Campinas, Campinas, 2013.

[35] C. Van Der Veen, "Bearing capacity of a pile," in Int. Conf. Soil Mech. Found. Eng., 1953, pp. 84-90.

[36] L. Décourt, "Ruptura de fundações e coeficientes de segurança a luz do conceito de rigidez," in An. XI COBRAMSEG, 1998, pp. 1599-1606.

[37] Associação Brasileira de Normas Técnicas, Projeto e Execução de Fundações, ABNT NBR 6122, 2019.

[38] M. M. Sales, Análise do Comportamento de Sapatas Estaqueadas. Brasília: Univ. Brasília, 2000.

Author contributions: JRG: conceptualization, formal analysis, methodology, writing, review and supervision; PJRA: funding acquisition, supervision and review.

Editors: Fernando Fonseca, José Luiz Antunes de Oliveira e Sousa, Guilherme Aris Parsekian. 